\title{
Inter-estuarine and temporal patterns of the fish assemblage of subtropical subestuaries along the Río de la Plata coast (Uruguay)
}

\author{
Alicia Acuña ${ }^{1}$, Nathalie Muñoz ${ }^{1}$, Rodrigo Gurdek ${ }^{2}$, Irene Machado ${ }^{3}$, Veronica Severi ${ }^{1}$ \\ ${ }^{1}$ Facultad de Ciencias. Oceanografía y Ecología Marina \\ (Igua 4225, 11400, Montevideo, Uruguay). \\ ${ }^{2}$ College of Science and Engineering \\ (James Cook University, Townsville, QLD 4811, Australia) \\ ${ }^{3}$ Ecología Funcional de Sistemas Acuáticos \\ (Centro Universitario Regional Este, Universidad de la República, Ruta 9 km 206, Rocha) \\ *Corresponding author: acuplavan@gmail.com
}

\section{Abstract}

Fish assemblages in subestuaries have been poorly studied worldwide. In order to evaluate the interestuarine and temporal variability of the ichthyofauna of subestuaries along the Uruguayan coast of the Río de la Plata (RdlP), the Pando, Solís Chico and Solís Grande systems were sampled between 2011 and 2013. Fish biomass, abundance, species richness and diversity indices were analysed, defining fish assemblages characterised by a few species and great abundance. Estuarine resident and freshwater species represented $55.5 \%$ of the fish assemblage according to estuarine use guilds. Species occurrence was similar in the three subestuaries, but the relative abundances differed among them. The analysed community parameters showed a decreasing trend from west to east along the Uruguayan coast. Highest diversity and fish abundance were recorded in the Pando system located in the proximities of an important spawning area in the inner RdlP estuary. In the Solís Grande subestuary occurred the lowest species richness and fish abundance. The Solís Chico was characterised as a transitional subsystem. All three subestuaries showed an increase in species richness and abundance during high temperature periods, probably related to the life cycle of the species sharing habitats between the RdlP and the coastal subestuaries. This study constitutes the first step in assessing the fish assemblage patterns in coastal ecosystems of the RdlP and an approach about the ecological role of the subestuaries in the southwest Atlantic Ocean.

Descriptors: Species diversity, Ichthyofauna, Estuarine systems, Variability patterns, South American estuaries, Community parameters.

Submitted on: 11/07/2016

Approved on: 11/10/2016

http://dx.doi.org/10.1590/S1679-87592017131106502

\section{RESUMO}

As assembleias de peixes em subestuários têm sido pouco estudadas no mundo. A fim de avaliar a variabilidade interestuarina e temporal da ictiofauna dos subestuários ao longo da costa uruguaia do Rio da Prata, foram amostrados entre 2011 e 2013 os sistemas Pando, Solís Chico e Solís Grande. A biomassa e abundância de peixes, riqueza de espécies e índices de diversidade foram analisadas, definindo-se que as assembleias de peixes são caracterizadas por apenas algumas espécies e com grande abundância. Espécies residentes estuarinas e de água doce apresentaram $55,5 \%$ da assembleia de peixes conforme as guildas de uso do estuário. Embora, a ocorrência de espécies tenha sido semelhante nos três subestuários, a sua abundância relativa foi diferente. Os valores dos parâmetros da comunidade mostraram uma tendência decrescente de oeste para leste ao longo da costa uruguaia. Maior diversidade de peixes e abundância foram registradas no sistema do Pando, localizado nas proximidades de uma importante área de desova no estuário do Rio da Prata interior. No subestuário do Solís Grande foram encontrados menor riqueza e abundância de peixes. Solís Chico foi caracterizado como um subsistema de transição. Os três subestuários mostraram um aumento na riqueza e abundância durante os períodos de temperatura alta, provavelmente relacionada com o ciclo de vida das espécies que compartilham hábitats entre o Rio da Prata e/ou os subestuários costeiros. Este estudo constitui o primeiro passo para avaliar os padrões de peixes no ecossistema costeiro do Rio da Prata e uma abordagem sobre o papel ecológico do subestuários no sudoeste do Oceano Atlântico.

Descritores: Diversidade de espécies, Ictiofauna, Sistemas estuarinos, Padrões de variabilidade, Estuários da América do Sul, Parâmetros comunitários. 


\section{INTRODUCTION}

Estuaries represent areas of ecological significance for a great number of species. They are relevant as transitional environments for the breeding, feeding and sheltering of fish species, many of them of commercial importance (WHITFIELD, 1999; MCLUSKY; ELLIOTT, 2004; DAY et al., 2013). The ichthyofauna knowledge provides good indicators of ecosystem structure and health (WHITFIELD; ELLIOTT, 2002) and is often the object of management concerns. Estuarine fish are subjected to the environmental stress from estuaries, affecting the distribution, abundance and migration of fish species during their life cycle (ELLIOTT et al., 2007). Likewise, factors such as biogeography, shape and size of the estuary, as well as habitat availability, have also been suggested to impact on species occurrence (POTTER; HYNDES, 1999; WHITFIELD, 1999; VALESINI et al., 2004; GUTIÉRREZ-ESTRADA et al., 2008; FRANÇA et al., 2009; NICOLAS et al., 2010).

Considering the relevance of estuarine ecosystems, the fish fauna from the Río de la Plata estuary (RdlP), as well as, of the coastal estuaries along the UruguayanArgentinian coast has been previously studied (LAGOS, 2003; JAUREGUIZAR et al., 2004, 2016; ACUÑA PLAVAN et al., 2010; LORENZO et al., 2011; GURDEK et al., 2011, 2016; SOLARI et al., 2015; GURDEK; ACUÑA PLAVAN, 2016). The RdIP is one of the largest estuaries worldwide, connected permanently to the Atlantic Ocean. As a complex hydrodynamic environment, it is characterized by a salt-wedge regime (ACHA et al., 2008). The displacement of the estuarine front along the Uruguayan coast depends on the discharges from its main tributaries, the Uruguay and Paraná rivers, and predominant winds (FRAMIÑAN; BROWN, 1996; PIOLA et al., 2005, PIOLA et al., 2008; MÖLLER et al., 2008). The fish species of the RdlP have been mainly group into the Sciaenidae, Clupeidae, Mugilidae, Atherinopsidae, Engraulidae, Paralichthydae and Pomatomidae families, some of them represented by species of commercial importance over the region (NORBIS et al., 2006; LORENZO et al., 2011). Among them species such as Micropogonias furnieri, Brevoortia aurea and Macrodon ancylodon present their reproductive areas in the RdIP during the austral spring (ACHA; MACCHI, 2000; MILITELLI et al., 2013).

A number of streams empty their waters into the Uruguayan coast of the RdIP, some of them forming small subestuaries (ACUÑA PLAVAN et al., 2015).
Among them, the Pando and Solís Grande subestuaries have been previously studied in terms of the benthic, planktonic and fish communities. In this sense, benthic and planktonic communities have been shown to describe different temporal patterns (GÓMEZ-ERACHE et al., 2000; CALLIARI et al., 2001; PASSADORE et al., 2007). Furthermore, these ecosystems has been suggested as nursery and juveniles areas for many commercial fish species (RETTA et al., 2006; DEFEO et al., 2009; ACUÑA PLAVAN et al., 2010; GURDEK et al., 2016). The fish assemblage has been studied providing daily (GURDEK et al., 2011), as well as monthly and spatial dynamics (ACUÑA PLAVAN et al., 2010, GURDEK et al., 2016). In spite of their proximity $(\sim 50 \mathrm{~km})$, these estuaries have shown some differences in fish species composition and abundance. In this sense, the whitemouth croaker Micropogonias furnieri inhabit the Pando subestuary on high abundance and annual basis (ACUÑA et al., 2010; GURDEK; ACUÑA PLAVAN, 2014; GURDEK; ACUÑA PLAVAN, 2016), while the silverside Odontesthes sp. (Atherinopsidae) and the mullet Mugil liza, are the most abundant species according to spatial-temporal studies in the Solís Grande subestuary (GURDEK et al., 2011; 2016).

Further studies, including new systems, as well broader temporal scales, are needed in order to provide a more comprehensive description of the fish assemblage from the small subestuaries along the Uruguayan coast. The aim of this study was to provide a characterization of the spatial and temporal patterns of the fish assemblage of three subestuaries along the Uruguayan coast of the RdlP between 2011 and 2013: Pando, Solís Chico and Solís Grande. Results will contribute to a better understanding of subestuarine fish composition and dynamics.

\section{MATERIAL AND METHODS}

\section{STUDY AREA}

The Río de la Plata (RdlP) is one of the largest estuaries in the world, discharging an average of 23,000 $\mathrm{m} 3 \mathrm{~s}^{-1}$ into the Atlantic Ocean (BORÚS et al., 2013). The RdlP is subdivided in a fluvial (inner) and estuarine (outer) region; the outer region covering an area of $35,000 \mathrm{~km}^{2}$ (FRAMIÑAN; BROWN, 1996). The Pando, Solís Chico and Solís Grande subestuaries are located in the outer region within a distance of $50 \mathrm{~km}$ along the Uruguayan coast of the RdlP estuary (Figure 1). These ecosystems 

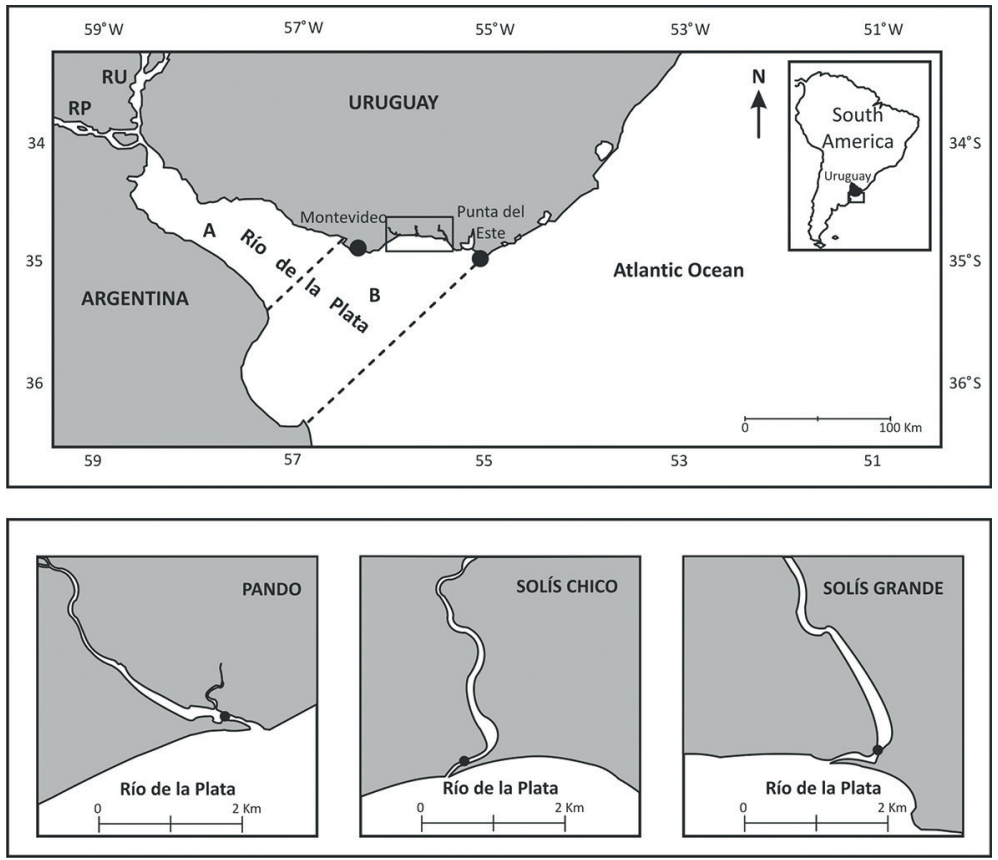

Figure 1. Location of the three sampling sites: Pando, Solís Chico and Solís Grande subestuaries of the Río de la Plata along the Uruguayan coast and fish sampling area in each estuary. $\mathrm{A}=$ upper and $\mathrm{B}=$ outer regions of the Río de la Plata. $\mathrm{RU}=$ Uruguay River; $\mathrm{RP}=\mathrm{Paraná}$ River.

are subject to similar weather conditions but differ in morphology and human impacts associated with the basins (FREPLATA, 2003).

The Pando subestuary (P) (Figure 1) is the western estuary and the smallest one with a drainage basin of $973 \mathrm{~km}^{2}$. The average flow is $6.4 \mathrm{~m}^{3} \mathrm{~s}^{-1}$, the average depth is $1.5 \mathrm{~m}$ and the maximum mouth width is $220 \mathrm{~m}$ (FREPLATA, 2003). High nutrient concentrations are characteristic of the estuary with frequent episodes of oxygen undersaturated waters (GOYENOLA et al., 2009). The subestuary presents a salinity range between 0 and 14 and a temperature range between 13 and $25^{\circ} \mathrm{C}$ during $\mathrm{El}$ Niño conditions (ACUÑA PLAVAN et al., 2010).

The Solís Chico subestuary (SCh) (Figure 1) lies between Pando and Solis Grande, has a drainage basin of $644 \mathrm{~km}^{2}$, average flow of $5.4 \mathrm{~m}^{3} \mathrm{~s}^{-1}$ and maximum width of $280 \mathrm{~m}$ (FREPLATA, 2003). The subestuary has a salinity range of 9-24 and a temperature range between 15 and 18 ${ }^{\circ} \mathrm{C}$ (GUTIÉRREZ et al., 2015). Population density around the basin is low and the main human activities are related to agriculture, forestry and summer tourism (GOYENOLA et al., 2009; ECHEVARRÍA et al., 2011).

The Solís Grande subestuary (SG) (Figure 1) is the eastern and largest estuary with a drainage basin of $1,354 \mathrm{~km}^{2}$, average flow $9.6 \mathrm{~m}^{3} \mathrm{~s}^{-1}$, mean depth $2 \mathrm{~m}$ and maximum width $330 \mathrm{~m}$ (FREPLATA, 2003). SG has the largest ranges of temperature $\left(10-25{ }^{\circ} \mathrm{C}\right)$ and salinity (4-33) (CALLIARI et al., 2001). This estuary is also characterised by low population density with main human activities related to agriculture, livestock, forestry, and tourism (GOYENOLA et al., 2009; ECHEVARRÍA et al., 2011).

\section{FISH SAMPLING}

Sampling was carried out during two consecutive years: spring 2011 (October), autumn 2012 (May), late winter 2012 (September), spring 2012 (November) and late summer 2013 (March). The samplings were carried out simultaneously, except for spring 2012 (P y SG) and summer 2013 (P). Fish were collected using a beach seine net $(12 \mathrm{~m}$ long with a central bag of $6.70 \mathrm{~m}$ long, mesh size $12 \mathrm{~mm}$ of cod-end and two lateral wings each of 5 $\mathrm{m}$ in length and of $2 \mathrm{~m}$ high). Additionally, to obtain a representative sampling of the species, two sets of gill nets (40 m long, $1.7 \mathrm{~m}$ high, each one with 4 different mesh sizes: 2, 3.5, 5.5 and $8 \mathrm{~cm}$ ) were placed at $200 \mathrm{~m}$ downstream and $1000 \mathrm{~m}$ upstream of the trawl fishing area. Twelve hauls were made on each sampling period, six on each margin of the subestuaries at approximately 
$1 \mathrm{~km}$ from the mouth, starting at sunrise and finishing no later than noon. Two ropes of $25 \mathrm{~m}$ were joined to each end of the beach seine net. One of the ropes was retained on the beach while the other end, together with the net, was deployed by a small rowing boat. The haul was made manually and perpendicular to the shore, keeping the net as close to the bottom as possible to cover an area of ca. $300 \mathrm{~m}^{2}$. All individuals were counted, measured to the nearest $0.1 \mathrm{~cm}$ and weighted to the nearest $0.1 \mathrm{~g}$ in field and laboratory. Juveniles and adults individuals were classified according to the maturity length available in literature.

Three replicates of Water temperature $\left({ }^{\circ} \mathrm{C}\right)$ and salinity were measured directly in the field with multiparameter Ysi Pro-plus (USA) with a temperature resolution of 0.1 ${ }^{\circ} \mathrm{C}$ and 0.01 for salinity.

\section{DATA ANALYSIS}

Only data from the beach seine were used to evaluate fish assemblage parameters (biomass, numerical abundance, richness and diversity indexes). Fish biomass and abundance were expressed in grams and number of individuals per $1000 \mathrm{~m}^{2}$, respectively. Additionally, considering the way fish use the estuary during their whole life cycle (based on the available literature), species were categorised by functional guilds according to FRANCO et al. (2008) and each species was assigned to an estuarine use functional guild (Table 2). The estuarine use functional guilds considered were marine stragglers, marine migrants, estuarine species, freshwater species, catadromous species and anadromous species. The percentage contribution of each functional guild to the total number of species was calculated. The Shannon and Simpson diversity indexes (SIMPSON, 1949; SHANNON; WEAVER, 1963) were used to analyse fish assemblage diversity. Assumptions of normality and homogeneity of variance were analysed by Shapiro Wilk's test (SHAPIRO; WILK, 1965) and Levene's test (based on the averages), respectively. When necessary, the data were previously transformed to $\log (\mathrm{x})$ or $\log (x+1)$. Parametric analysis of variance (ANOVA) or non-parametric Kruskal-Wallis was used depending on the fulfilment of the assumptions to contrast fish community parameters. A posteriori Tukey Test or Mann-Whitney was used to test multiple comparisons. Differences in fish assemblages among subestuaries were examined using non-metric multidimensional scaling (nMDS) by using the Bray-Curtis similarity index. Prior to calculation of the Bray Curtis index, the abundance (individuals $\mathrm{x} 1000 \mathrm{~m}^{2}$ ) was transformed to fourth-root to reduce the contribution of the abundant species. Analysis of similarity (ANOSIM) was carried out on the above data to determine the significance of fish assemblage differences or similarities between subestuaries and periods. The level of significance used was $p=0.05$ (SOKAL; ROHLF, 1995). The PRIMER software package (Version 6.0, Inc.) and Past (Version 3.0) were utilized to conduct the analyses.

\section{RESULTS}

\section{ENVIRONMENTAL VARIABLES}

The average water temperature varied between seasons, showing an increase during spring 2012 (23.1 $\left.{ }^{\circ} \mathrm{C}\right)$ and summer $2013\left(23.8^{\circ} \mathrm{C}\right)$ (Table 1). No differences were found between sites (Kruskal-Wallis, $p>0.05$ ). The salinity varied between 7.5 (autumn 2012) in Pando and 25.5 (autumn 2012) in the Solís Grande (Table 1).

\section{FISH COMPOSITION AND SPECIES OCCURRENCE}

Overall a total of 8,271 individuals belonging to 15 families and 18 species were recorded in the three subestuaries (Table 2). In terms of species richness the fish assemblage was represented by $33.3 \%$ estuarine species, $22.2 \%$ freshwater species, $16.7 \%$ marine stragglers, $11.1 \%$ marine migrants, $11.1 \%$ anadromous species and $5.6 \%$ catadromous species. While Sciaenidae and Clupeidae were the most abundant families in terms of species richness, other families such as Cyprinidae (represented by Cyprinus carpio), Pimelodidae (represented by Pimelodus maculatus) and Anablepidae (represented by Jenynsia multidentata) occurred with a single species and individual. Larvae individuals classified as Clupeidae were captured only in P, while Gobiosoma parri, Hypleurochilus fissicornis and Syngnathus folletti only in SCh (Table 2). All three subestuaries showed similar fish species composition (Table 2). However, they showed differences in terms of species relative abundance (Figure 2). In this sense, in the P subestuary, Brevoortia aurea, Mugil liza, Micropogonias furnieri, Odontesthes argentinensis, Lycengraulis grossidens and Platanichthys platana made up $99 \%$ of all the fish sampled, with $B$. aurea and $M$. liza accounting for more than $50 \%$ of the total. While in Solís Chico, the fish assemblage was dominated by species such as B. aurea, P. platana, M. liza, O. argentinensis and M. furnieri, similar than in $\mathrm{P}$ (B. aurea, M. liza, O. argentinensis, $M$. furnieri). In Solís Grande, O. argentinensis dominated 
Table 1. Average \pm standard deviation of temperature $\left(\mathrm{T}-{ }^{\circ} \mathrm{C}\right)$ and salinity $(\mathrm{S})$ of water in Pando (P), Solís Chico (SCh) and Solís Grande (SG) subestuaries during five seasons (Spr- spring 2011, Aut- autumn 2012, Win- winter 2012, Spr- spring 2012 and Sum- summer 2013).

\begin{tabular}{lcccccccccccc}
\hline & P & SCh & SG & P & SCh & SG & P & SCh & SG & P & SG & P \\
& & Spr 2011 & & & Aut 2012 & & & Win 2012 & & Spr 2012 & Sum 2013 \\
\hline $\mathrm{T}\left({ }^{\circ} \mathrm{C}\right)$ & $14.7 \pm 0.7$ & $15.2 \pm 0.8$ & $14.1 \pm 1.1$ & $16.3 \pm 0.4$ & $17.8 \pm 0.6$ & $17.6 \pm 0.6$ & $14.2 \pm 0.1$ & $15.2 \pm 0.2$ & $16.3 \pm 1.6$ & $23.1 \pm 1.3$ & $20.2 \pm 0.6$ & $23.8 \pm 3.5$ \\
$\mathrm{~S}$ & $20.9 \pm 6.2$ & $21.4 \pm 5.8$ & $21.8 \pm 8.7$ & $7.5 \pm 7.3$ & $13.4 \pm 9.2$ & $25.5 \pm 8.0$ & $8.4 \pm 0.2$ & $9.9 \pm 2.2$ & $9.9 \pm 5.3$ & $13.6 \pm 7.0$ & $20.1 \pm 4.5$ & $21.1 \pm 0.5$ \\
\hline
\end{tabular}

the fish community (69\%), followed by Paralichthys orbignyanus (12.7\%) and M. liza (10.3\%) (Figure 2). Estuarine resident species dominated the fish community in $\mathrm{P}(50 \%)$, SCh (33.3\%) and SG (50\%) subestuaries, followed by freshwater (16.7\%) and anadromous species $(16.7 \%)$ in $\mathrm{P}$, marine stragglers (25\%) in SCh and equal proportions of freshwater, marine migrants, anadromous and catadromous species (12.5\%) in SG.

In relation to the temporal variability and environmental conditions some species patterns were observed. Brevoortia aurea, M. liza, M. furnieri and L. grossidens showed the highest density in $\mathrm{P}$ during summer, with an average water temperature and salinity of $23.8{ }^{\circ} \mathrm{C}$ and 21.1 respectively (Table 2; Table 1). Micropogonias furnieri was not caught during winter in any subestuary (Table 2). Platanichthys platana and Odontesthes argentinensis were mostly captured during autumn in all subestuaries with temperature values around $17{ }^{\circ} \mathrm{C}$, however the salinity values were highly variable among the systems (Table 2; Table 1). Paralichthys orbignyanus on the other hand, was mostly caught in SG in autumn and spring 2012 (T values around $19{ }^{\circ} \mathrm{C}$, S: 20.1-25.5) but also was only captured in SCh during autumn and in P during spring 2012 with similar temperature (mean 13.4) and salinity values (mean 13.6) (Table 2; Table 1).

Some differences were observed in the captures according to fishing gears (Table 2). However, Micropogonias furnieri and Brevoortia aurea presented high abundances regardless of the sampling gear. Some species were only captured by gill net depending on the site and sampling periods (e.g. Pomatomus saltatrix in P, Pogonias cromis in SCh and $M$. furnieri in SG). The length range of species was different between individuals caught by beach seine or gill net. Individuals captured by gill net were fundamentally represented by larger sizes. The most abundant species (i.e. B. aurea, M. liza, O. argentinensis, M. furnieri) presented the smallest sizes, denoting the occurrence of Clupeidae larvae during beach seine netting (Table. 2).
INTER-ESTUARINE AND TEMPORAL VARIATIONS IN FISH ASSEMBLAGES

According to spatial variability of the community parameters, the average biomass ranged from $979 \pm 1,220$

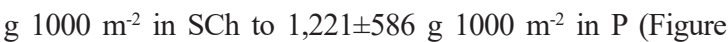
3 a). The highest biomass was found in SCh, as well as in SG during winter 2012 (Kruskal Wallis, $p<0.05$ ) (Figure $3 b)$. These values were recorded due to larger specimens of Cyprinus carpio $(7,815 \mathrm{~g})$ in SCh and Paralichthys orbignyanus $(310.5-8,492 \mathrm{~g})$ in SG. In other periods, the biomass was higher in P and SG than in SCh (e.g. spring 2011 and autumn 2012). In terms of density, the highest average abundance was registered in $\mathrm{P}(399 \pm 518$ individuals $1000 \mathrm{~m}^{-2}$ ) (Kruskal Wallis, $p<0.05$ ), followed by $\mathrm{SCh}$ and SG (Figure $3 \mathrm{c}$ ). This pattern was found in all periods with the exception of winter 2012, when differences were only significant between $\mathrm{P}$ and SG (Mann Whitney, $p<0.05$ ) (Figure $3 \mathrm{~d}$ ). The highest abundance occurred during autumn 2012, in all three subestuaries (Kruskal Wallis, $p<0.05$ ).

Once again, the average species richness and diversity was higher in $\mathrm{P}$ than in SG (Mann Whitney, $p<0.05$ ) (Figure 3 e, g). There were differences between P and SG during spring 2011 and autumn 2012 (Kruskal Wallis, $p<0.05$; Figure $3 \mathrm{f}, \mathrm{h}$ ). SCh showed similarities and discrepancies with the $\mathrm{P}$ and $\mathrm{SG}$ according to the sampling period (in spring 2011 and autumn 2012). Autumn 2012 was the period with the highest occurrence of fish species in all subestuaries (Figure $3 \mathrm{f}$ ).

Regarding the comparison of fish diversity among the 3 subsystems when they were sampled together, results showed a minimum in diversity in all subestuaries during the winter, when mean temperature values ranged from 14.2 to $16.3^{\circ} \mathrm{C}$ and salinities were lowest between 8.4 to 9.9 (Figure 3h; Table 1). Highest diversity occurred in autumn in all systems when temperature was higher (Figure $3 \mathrm{~h}$; Table 1).

The nMDS ordination based on individuals per species showed that $\mathrm{P}$ and $\mathrm{SG}$ are the most dissimilar systems, while SCh presents similarities with P and SG (Figure 4). Similarly, ANOSIM results, revealed that each estuary differed significantly with each other, although overlapping community characteristics $(\mathrm{R}=0.344, p<0.05)$. Paired 
Acuña et al.: Fish assemblage in Uruguayan subestuaries

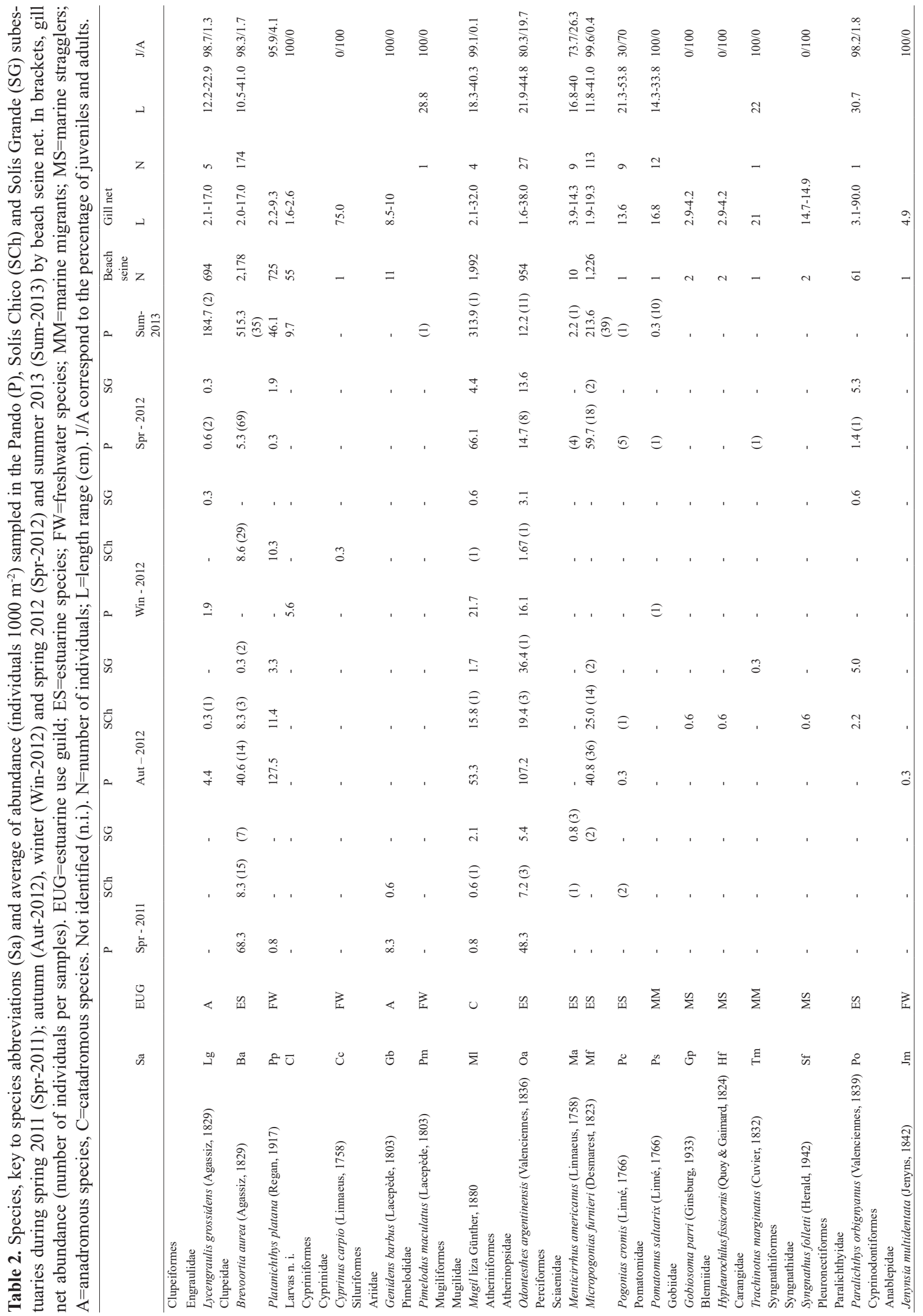

178

BRAZILIAN JOURNAL OF OCEANOGRAPHY, 65(2):173-186;2017 

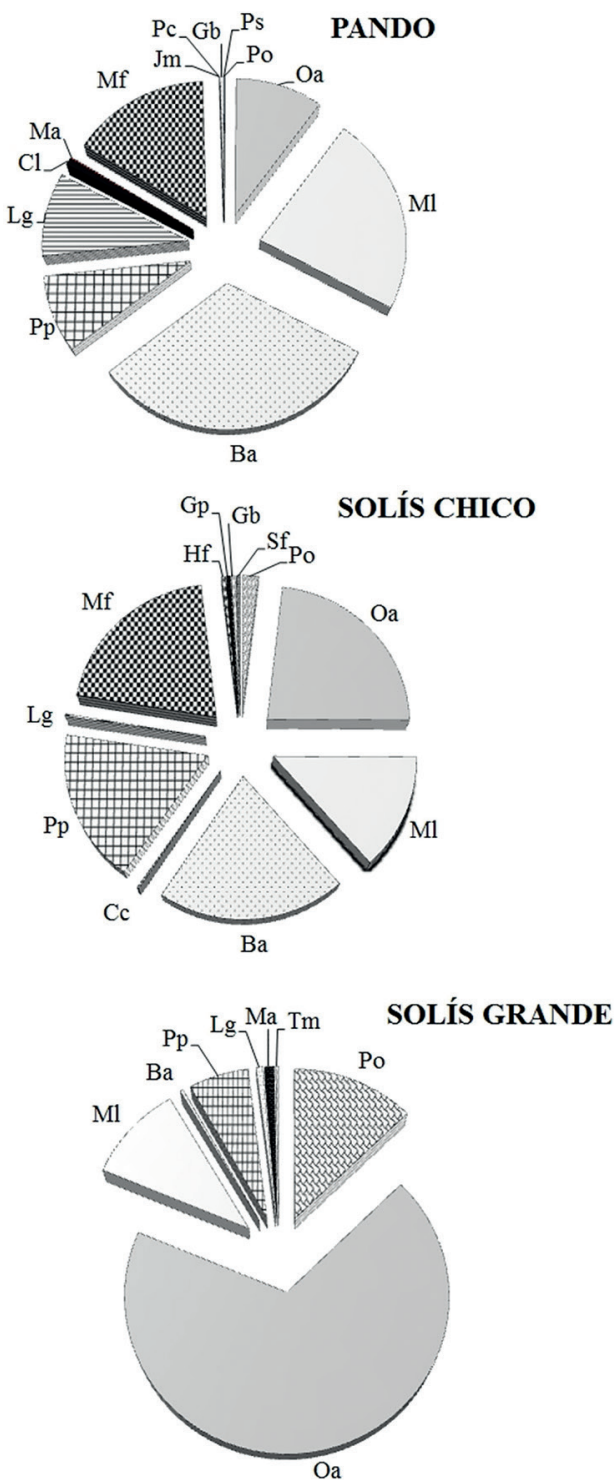

Figure 2. Relative abundance of fish species (individuals $1000 \mathrm{~m}^{-2}$ ) based on beach seine in the Pando (P), Solís Chico (SCh) and Solís Grande (SG) subestuaries. Key of species abbreviations in Table 2.

comparisons indicated a significant difference between $\mathrm{P}$ and $\mathrm{SG}(\mathrm{R}=0.431, p<0.05)$. However, there were not significant differences between $\mathrm{P}$ and $\mathrm{SCh}(\mathrm{R}=0.138$, $p>0.05)$, or between $\mathrm{SCh}$ and $\mathrm{SG}(\mathrm{R}=0.481, p>0.05)$, showing a more similar community between $\mathrm{P}$ and $\mathrm{SCh}$.

\section{DISCUSSION}

\section{FAMILIES AND SPECIES COMPOSITION}

The families and species found in the three subestuaries sampled in the present study are similar to those found in subestuaries and other estuarine ecosystems along the Uruguayan coast (RETTA et al., 2006; ACUÑA PLAVAN et al., 2010; TEIXEIRA DE MELLO et al., 2011), southern coast of Brazil (CHAO et al., 1985; VIEIRA; MUSICK, 1994; RAMOS; VIEIRA, 2001), north eastern coast of Argentina (GONZÁLEZ-CASTRO et al., 2009; SOLARI et al., 2009; COUSSEAU et al., 2011; BRUNO et al., 2013; SOLARI, 2013).

Fish assemblages from Pando, Solís Chico and Solís Grande subestuaries were characterised by a few dominant species (Micropogonias furnieri, Brevoortia aurea, Mugil 

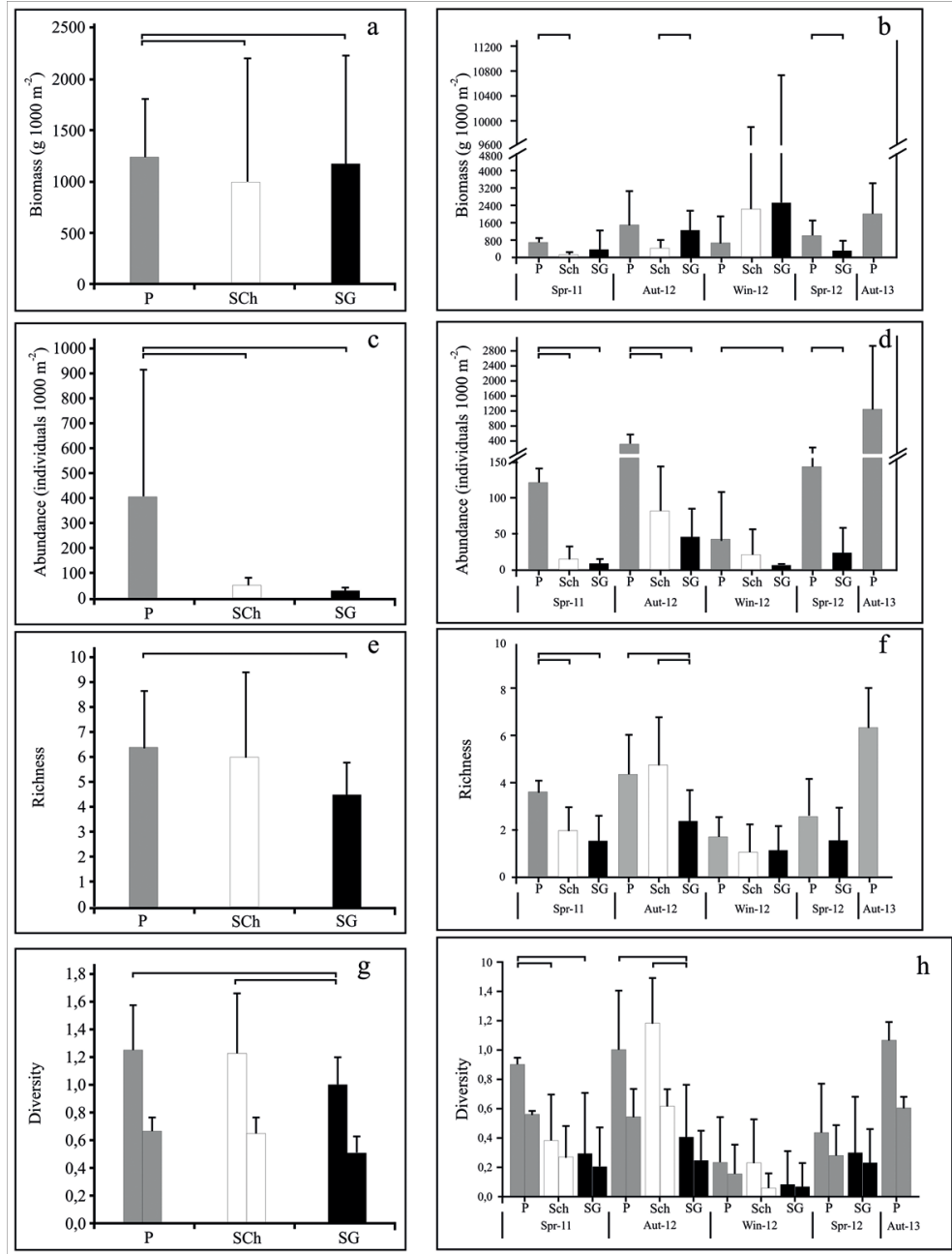

Figure 3. Biomass $\left(\mathrm{g} 1000 \mathrm{~m}^{-2}\right)(\mathrm{a}, \mathrm{b})$, abundance $(\mathrm{c}, \mathrm{d})$ (individuals $\left.1000 \mathrm{~m}^{-2}\right)$, richness $(\mathrm{e}, \mathrm{f})$ and diversity indices $(\mathrm{g}, \mathrm{h})$ (Shannon index: left bar; Simpson index: right bar) from the fish community from the Pando ( $\mathrm{P}=$ grey column), Solís Chico $(\mathrm{SCh}=$ white column) and Solis Grande (SG=black column) subestuaries during spring 2011 (Spr-11), autumn (Aut-12), winter (Win-12) and spring (Spr-12) 2012 and summer 2013 (Sum- 13). The columns represent mean values and the vertical bars on top of the columns are standard deviations. Horizontal lines represent significant differences between subestuaries $(p<0.05)$.

liza, Odontesthes argentinensis, Paralichthys orbignyanus) with high abundance and mainly belonging to the category resident estuarine species. It is a typical characteristic from temperate estuaries worldwide (BLABER, 2002; VEIGA et al., 2006; GONZÁLEZ-CASTRO et al., 2009; ACUÑA PLAVAN et al., 2010; VASCONCELOS et al., 2011; GURDEK et al., 2016). The composition of fish assemblages in the subestuaries of the Uruguayan coast also included marine stragglers and freshwater species of occasional temporal and estuarine occurrence. For instance, Syngnathus folletti, Hypleurochilus fissicornis and Gobiosoma parri, occurred only in SCh, while the freshwater species Pimelodus maculatus, Jenynsia multidentata and Cyprinus carpio were captured only in $\mathrm{P}$ and SCh. The sampling site, i.e. the mouth of the subestuary, was probably the determinant factor for the low capture of freshwater species. Marine species were underrepresented in all three subestuaries in contrast to many estuarine systems (FRANCO et al., 2008; NICOLAS et al., 2010; CARDOSO et al., 2011).

Regarding the fishing gear, some differences were observed in the captures. Differences in catches according to the fishing gear indicate gear selectivity (schools, patchy distribution, species characteristics) (ELLIOTT; 


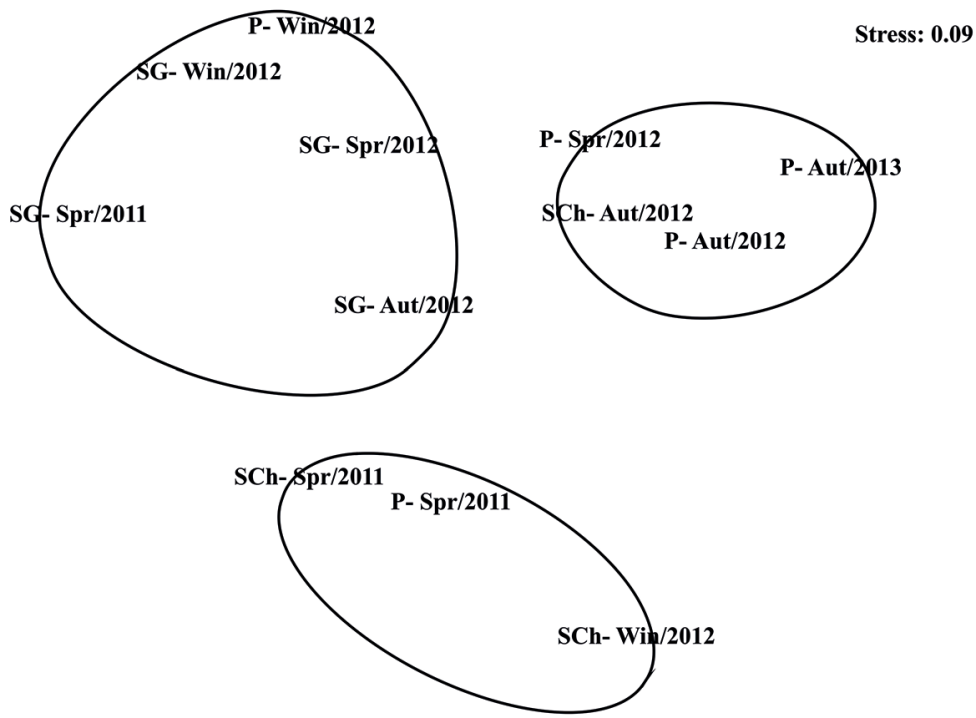

Figure 4. Multi-Dimensional Scaling (MDS) based on abundance of fish samples collected in the Pando (P), Solís Chico (SCh) and Solís Grande (SG) subestuaries during different sampling periods. Spr/2011 (spring 2011), Aut/2012 (autumn 2012), Win/2012 (winter 2012), Spr/2012 (spring 2012), Sum/2013 (summer 2013).

HEMINGWAY, 2002). It is important to include different sampling gears to enhance the representation of the fish community (FRANCO et al., 2012).

\section{INTER-ESTUARINE PATTERNS IN FISH ASSEMBLAGES}

In general terms, the abundance, species richness and diversity followed an eastward decreasing trend among subestuaries; probably related to the estuarine-ocean gradient regarding of the RdIP (JAUREGUIZAR et al., 2004; LORENZO et al., 2011; LAGOS, 2003). This feature supports the study of RETTA et al. (2006) who found that abundance and species richness decreases from the inner to the outer part of the Uruguayan cost of RdlP. In order to understand the spatial distribution of fish assemblages from the P, SCh and SG subestuaries, it is necessary to consider their links with the larger RdlP estuary. These subestuaries are influenced by the highly dynamic RdlP system, where freshwater discharge and regional winds, and tides to a lesser extent, displace and mix its waters (NAGY et al., 2008; JAUREGUIZAR et al., 2016). Variation in spatial distribution of fish assemblage in estuaries can be attributed to contrasting marine conditions (HARRISON; WHITFIELD, 2006; GONZÁLEZ-CASTRO et al., 2009; NICOLAS et al., 2010). The SG subestuary presented the lowest abundance, richness and diversity of the community probably related to the estuarine-ocean gradient of the RdIP (FRAMIÑAN; BROWN，1996; JAUREGUIZAR et al., 2016). In this subestuary dominated Odontesthes argentinensis, a shallow-water pelagic fish known by its marine affinities and inhabits both estuarine and inshore waters (MORESCO; BEMVENUTI, 2006). The large phenotypic plasticity of this species allows it to adapt to a wide range of salinities (LLOMPART et al., 2013). We need to highlight the high abundance and diversity of species in the $\mathrm{P}$ subestuary probably related to the proximity to reproduction and breeding areas located in the inner RdlP estuary (ACHA; MACCHI, 2000; ACHA et al., 2008) such Micropogonias furnieri and Brevoortia aurea species. Regarding the fish assemblage composition of $\mathrm{SCh}$, it showed more similarities with $\mathrm{P}$ than with SG. This could be associated to the location of SCh in between both systems. It is worthwhile highlight that $\mathrm{SG}$ is located next to the RdlP external limit. Outer conditions of the RdlP probably affect the $\mathrm{SCh}$ composition in a more similar way than it does to P. The SCh subestuary can be considered a transitional ecosystem.

Differences of biomass, abundance and species diversity among three subestuaries may also respond to inherent estuarine factors such as shape, size, depth, habitat-type availability and freshwater flow of the estuary (BLABER, 2000; HARRISON; WHITFIELD, 2006; FRANÇA et al., 2012) and factors influencing the connection to the RdlP system (e.g. mouth width and opening). In this regard, the morphology of the lower section of $\mathrm{P}$ and $\mathrm{SCh}$ determines 
a more direct connection with the brackish waters of the RdlP (FREPLATA, 2003; ECHEVARRÍA et al., 2011). The SCh has a large area occupied by salt marshes located near the sampled area (FREPLATA, 2003), which could explain the high diversity specified in taxonomic terms (some species captured only there) and evenness (the lack of dominance). These habitats provide shelter and food resources to the fish community, hence influencing the community parameters found along the estuaries (FRANÇA et al., 2009; NICOLAS et al., 2010).

\section{TEMPORAL VARIABILITY OF FISH ASSEMBLAGES}

Species richness and abundance varied temporally in the three subestuaries, with peaks in warm periods and lows in cold periods. Temperature is the primary abiotic factor controlling life history patterns of fish (THIEL et al., 1995; HARRISON; WHITFIELD, 2006). In Mar Chiquita coastal lagoon, Argentina, species such as Brevoortia aurea, Micropogonias furnieri, Mugil liza and Odontesthes argentinensis were more abundant during the warm season (October-March) (COUSSEAU et al., 2011). On the other hand, low species richness is a common pattern found during the cold seasons (autumn-winter) (JAMES et al., 2007; FRANÇA et al., 2008; SELLESLAGH; AMARA, 2008; CARDOSO et al., 2011; FOWLER; BOOTH, 2013). From October 2002 to March 2003, ACUÑA PLAVAN et al. (2010) found a seasonal variability in the abundance of the fish community of $\mathrm{P}$ subestuary with a high predominance of B. aurea and M. furnieri during March 2003 (late summer).
For instance, estuarine resident species showed higher abundances during winter in Portuguese small estuaries while seasonal species using these areas as nurseries or feeding grounds were higher during summer and autumn (CARDOSO etal., 2011). Estuaries represent a fundamental link fornumerous fish species, which use them during specific life stages (in an obligatory or opportunistic way) (VASCONCELOS et al., 2011). The use of the estuary of large RdIP estuary according to the life cycle of species could explain the temporal patterns in the subestuaries. The spatial and temporal distribution of fish assemblages in the RdlP has been extensively studied (DÍAZ DE ASTARLOA et al., 1999; JAUREGUIZAR et al., 2003a, 2006; GARCÍA et al., 2010; LORENZO et al., 2011) finding an occurrence of similar species between RdlP and the three subestuaries. This is the case of estuarine species, such as M. furnieri, Menticirrhus americanus, Pogonias cromis, $B$. aurea and Paralichthys orbignyanus, marine migrant species represented by Trachinotus marginatus, catadromous species such as Mugil liza and anadromous species like Genidens barbus. The life cycles (maturity, spawning, larval and juvenile growth) of these species occur within a specific period and location in the RdIP (JAUREGUIZAR et al., 2003b; ACHA et al., 2008; LORENZO et al., 2011; MILITELLI et al., 2013). The large RdIP estuary allows reproductive opportunities for fish species as well as constitutes the habitat of fish larvae, developing similar ecological functions than the oceanic coastal systems. In this sense, the life cycle of the whitemouth croaker M. furnieri is related to the RdlP system but also to smaller subestuarine systems, as shown in figure 5. According

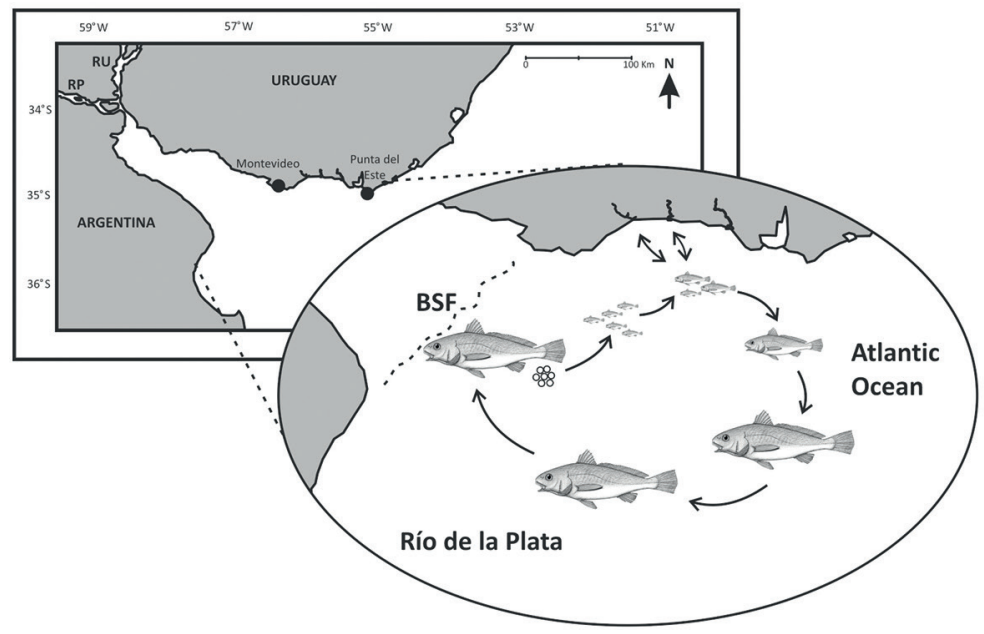

Figure 5. Schematic design of life cycle of Micropogonias furnieri in the Río de la Plata estuary and Uruguayan coast. The fish size and arrows direction show the adults spawning distribution in the bottom salinity front (BSF), subadults in the mouth of the RdIP and juveniles distributed between the subestuaries of the Uruguayan coast and RdlP. Pando=P; Solís Chico=SCh; Solís Grande=SG. Modified from GOYENOLA et al. (2009). 
to JAUREGUIZAR et al. (2003b) the younger age classes $(<2$ years) are located in the same region of the RdlP during early winter and spring. A higher abundance of the same age classes of the species were registered in P from November 2002 to March 2003 (from spring to summer) by ACUÑA PLAVAN et al. (2010), as well as of juveniles during March 1999 and January 2000 (summer) by MARTÍNEZ and RETTA (2002). ACHA et al. (2008) suggested a displacement of the young-ofthe-year $M$. furnieri individuals to shallow and protected areas of the Uruguayan coast after spawning season.

The role of subestuaries in the life cycle of fish species, and hence the connectivity between their populations and the ones from larger estuaries should receive further attention.

\section{ACKNOWLEDGMENTS}

We thank the fisherman Alfredo Hargain for his participation in the sampling activities, as well as the Professor Rafael Arocena and the Limnology laboratory (Facultad de Ciencias, Universidad de la República) for lending us the boat. We also thank the IctioEstuarios Project team: Ruben Canavesse, Juan Gutierrez, Patricia Correa, Samanta Stebniki, Vernadet Bianchinotti, Andrés de la Rosa, Martín Sosa, Martín Spósito and Diego Corrales who helped us in field and laboratory activities. This work was funded by a full time program of Universidad de la República (2012-2013), Postgraduate program (PEDECIBA, 2012) and Initial Fellowship (ANII program, Agencia Nacional de Investigación e Inovación, 2011-2012). Special thanks to Dr. Beatriz Baliño, University of Bergen, for technical recommendations and proof reading.

\section{REFERENCES}

ACHA, E. M., MIANZAN, H.; GUERRERO, R.; CARRETO, J.; GIBERTO, D.; MONTOYA, N.; CARIGNAN. M. An overview of physical and ecological processes in the Río de la Plata Estuary. Cont. Shelf Res., v. 28, n. 13, p. 1579-1588, 2008.

ACHA, E. M.; MACCHI G. J. Spawning of Brazilian menhaden, Brevoortia aurea, in the Río de la Plata estuary off Argentina and Uruguay. Fish. Bull., v. 98, n. 2, p. 227-235, 2000.

ACUÑA PLAVAN, A.; PASSADORE C.; GIMENEZ, L. Fish assemblage in the temperate estuary on the Uruguayan coast: seasonal variation and environmental influence. Braz. J. Oceanogr., v. 58, n. 4, p. 299-314, 2010.

ACUÑA PLAVAN, A.; VEROCAI, J.; GURDEK, R.; MUÑOZ, N.; CANAVESE, R.; MACHADO, I.; DE LA ROSA, A.; SEVERI, V.; STEBENIKI, S.; GUTIERREZ, J.; CORREA, P. Estuarios del Uruguay. Biodiversidad y estructura de la asociación de peces. In: MUNIZ, P.; CONDE, D.; VENTURINI, N.; BRUGNOLI, E.
(Compiladores). Ciencias marino-costeras en el umbral del siglo XXI: Desafios en Latinoamérica y el Caribe. Ciudad de México: AGT- Editor S.A, 2015.

BLABER, S. J. M. 'Fish in hot water': the challenges facing fish and fisheries research in tropical estuaries. J. Fish Biol., v. 61, n. sA, p. 1-20, 2002.

BLABER, S. J. M. Tropical estuarine fishes: ecology, exploitation and conservation. Oxford: Blackwell Science, 2000. 372 p.

BORÚS, J.; URIBURU QUIRNO, M.; CALVO, D. Evaluación de caudales diarios descargados por los grandes ríos del sistema del Plata al estuario del Río de la Plata. In: Alerta Hidrológico. Ezeiza: Instituto Nacional del Agua y el Ambiente, 2013.

BRUNO, D. O.; BARBINI, S. A.; DÍAZ DE ASTARLOA, J. M.; MARTOS, P. Fish abundance and distribution patterns related to environmental factors in a choked temperate coastal lagoon (Argentina). Braz. J. Oceanogr., v. 61, n. 1, p. 43-53, 2013.

CALLIARI, D.; CERVETTO, G.; GÓMEZ, M. Short-temporal variability in abundance and vertical distribution of the opossum shrimp Neomysis americana in the Solís Grande river estuary, Uruguay. Atlântica, v. 23, p. 117-125, 2001.

CARDOSO, I.; FRANÇA, S.; PESSANHA PAIS, M.; HENRIQUES, S.; CANCELA DA FONSECA, L.; CABRAL, H. N. Fish assemblages of small estuaries of the Portuguese coast: A functional approach. Estuar. Coast. Shelf Sci., v. 93, n. 1, p. 40-46, 2011.

CHAO, L. H.; PEREIRA, L. E.; VIERA, J. P. Estuarine fish community of the dos Patos Lagoon, Brazil. A baseline study. In: YAÑEZ-ARANCIBIA, A. (Ed.). Fish Community Ecology in Estuaries and Coastal Lagoon: Towards an Ecosystem Integration. Ciudad de Mexico: UNAM Press, 1985. p. 429-450.

COUSSEAU, M. B.; MARCHESI, M. C.; FIGUEROA, D. E.; DÍAZ DE ASTARLOA, J. M.; GONZÁLEZ-CASTRO, M. Relación íctica entre la laguna costera Mar Chiquita y el mar adyacente. Hist. Nat., v. 1, n. 2, p. 85-100, 2011.

DAY, J. W. JR.; CRUMP, B. C.; KEMP, W. M.; YÁÑEZARANCIBIA, A (Eds.). Introduction to estuarine ecology. In: DAY, J. W. JR.; CRUMP, B. C.; KEMP, W. M.; YAÑEZARANCIBIA, A. (Eds.). Estuarine Ecology. $2^{\text {nd }}$ ed. Hoboken: John Wiley and Sons, 2013. 568 p.

DEFEO, O.; HORTA, S.; CARRANZA, A.; LERCARI, D.; DE ALAVA, A.; GOMEZ, J.; MARTINEZ, G.; LOZOYA, J. P.; CELENTANO, E. Hacia un Manejo Ecosistémico de Pesquerías. Áreas Marinas Protegidas en Uruguay. Montevideo: Facultad de Ciencias-DINARA, 2009. 122 p.

DÍAZ DE ASTARLOA, J. M.; AUBONE, A.; COUSSEAU, M. B. Asociaciones ícticas de plataforma costera de Uruguay y norte de Argentina, y su relación con los parámetros ambientales. Physis, v. 57, p. 29-45, 1999.

ECHEVARRÍA, L.; GÓMEZ, A.; LALE, M.; LÓPEZ, R.; NIETO, P.; PEREYRA, G. Plan de Manejo Integrado del tramo de costa $\mathrm{A}^{\circ}$ Solís Chico $-\mathrm{A}^{\circ}$ Solís Grande. In: Centro Interdisciplinario para el Manejo Costero Integrado del Cono Sur. CIDA/UDELAR, Universidad de la República. (Eds.). Manejo Costero Integrado en Uruguay: ocho ensayos interdisciplinarios. Montevideo: Centro Interdisciplinario para el Manejo Costero Integrado del Cono Sur. 2011. p. 123152.

ELLIOTT, M.; HEMINGWAY, K. L. Fishes in Estuaries. Oxford: Blackwell Science, 2002. 360 p. 
ELLIOTT, M.; WHITFIELD, A. K.; POTTER, I. C.; BLABER, S. J. M.; CYRUS, D. P.; NORDILE, F. G.; HARRISON, T. D. The guild approach to categorizing estuarine fish assemblages: a global review. Fish Fish., v. 8, n. 3, p. 241268, 2007.

FOWLER, A. M.; BOOTH, D. J. Seasonal Dynamics of Fish Assemblages on Breakwaters and Natural Rocky Reefs in a Temperate Estuary: Consistent Assemblage Differences Driven by Sub-Adults. PloS ONE, v. 8, n. 9, p. e75790, 2013.

FRAMIÑAN, M. B.; BROWN, O. B. Study of the Río de la Plata turbidity front, Part 1: spatial and temporal distribution. Cont. Shelf Res., v. 16, n. 10, p. 1259-1267, 1269-1282, 1996.

FRANÇA, S.; COSTA, M. J.; CABRAL, H. N. Assessing habitat specific fish assemblages in estuaries along the Portuguese coast. Estuar. Coast. Shelf Sci., v. 83, n. 1, p. 1-12, 2009.

FRANÇA, S.; PARDAL, M. A.; CABRAL, H. N. Mudflat nekton assemblages in the Tejo estuary (Portugal): distribution and feeding patterns. Sci. Mar., v. 73, n. 2, p. 591-602, 2008.

FRANÇA, S.; VASCONCELOS, R. P.; FONSECA, V. F.; TANNER, S. E.; REIS-SANTOS, P.; COSTA, M. J.; CABRAL, H. N. Predicting fish community properties within estuaries: Influence of habitat type and other environmental features. Estuar. Coast. Shelf Sci., v. 107, p. 22-31, 2012.

FRANCO, A.; ELLIOTT, M.; FRANZOI, P.; TORRICELLI, P. Life strategies of fishes in European estuaries: the functional guild approach. Mar. Ecol. Prog. Ser., v. 354, p. 219-228, 2008.

FRANCO, A.; PÉREZ-RUZAFA, A.; DROUINEAU, H.; FRANZOI, P.; KOUTRAKIS, E. T.; LEPAGE, M.; VERDIELL-CUBEDO, D.; BOUCHOUCHA, M.; LÓPEZCAPEL, A.; RICCATO, F.; SAPOUNIDIS, A.; MARCOS, C.; OLIVA-PATERNA, F. J.; TORRALVA-FORERO, M.; TORRICELLI, P. Assessment of fish assemblages in coastal lagoon habitats: Effect of sampling method. Estuar. Coast. Shelf Sci., v. 112, p. 115-125, 2012.

FREPLATA (Frente Marítimo del Río de la Plata); LASTA, C.; PERDOMO, A.; CARSEN, A.; FERNÁNDEZ, V.; REY, L.; CALLIARI, D.; RESNICHENKO, Y.; STRELZIK, A.; BECCAR, A.; GONIADZKI, D.; ORIBE, J.; FLORES, M.; SOLDANO, A. Cuencas Hidrográficas tributarias al Río de la Plata y su Frente Maritimo. Documento de trabajo $N^{\circ}$ 3. Proyecto "Protección Ambiental del Río de la Plata y su Frente Marítimo: Prevención y Control de la Contaminación y Restauración de Hábitats". Proyecto FREPLATA, Montevideo: Laboratorio de Técnicas Aplicadas al Análisis del Territorio, Facultad de Ciencias, Universidad de la Republica, 2003.

GARCÍA, M. L.; JAUREGUIZAR, A. J.; PROTOGINO, L. C. From fresh water to the slope: fish community ecology in the Río de la Plata and the sea beyond. Lat. Am. J. Aquat. Res., v. 38 , n. 1, p. 81-94, 2010

GÓMEZ-ERACHE, M.; NORBIS, W.; BASTRERI, D. Wind effect as forcing factor controlling distribution and diversity of copepods in a shallow temperate estuary (Solís Grande, Uruguay). Sci. Mar., v. 64, n. 1, p. 87-95, 2000.

GONZÁlEZ-CASTRO, M.; DÍAZ DE ASTARLOA, J. M.; COUSSEAU, M. B.; FIGUEROA, D. E.; DELPIANI, S. M.; BRUNO, D. O.; GUZZONI, J. M.; BLASINA, G. E.; DELLI ANTONI, M. Y. Fish composition in a south-western Atlantic temperate coastal lagoon: spatial-temporal variation and relationships with environmental variables. J. Mar. Biol. Assoc. UK., v. 89, n. 3, p. 593-604, 2009.
GOYENOLA, G.; ACEVEDO, S.; MACHADO, I.; MAZZEO, N. Estado del Ambiente. In: Programa de las naciones unidas para el medio ambiente. Geo Canelones: Informe Ambiental. Montevideo: PNUMA/IMC, 2009. p. 59-137.

GURDEK, R.; ACUÑA PLAVAN, A. Weight-length relationships of 12 fish species from the Pando tidal creek estuary (subsystem of the Río de la Plata, Uruguay). J. Appl. Ichthyol., v. 30, n. 2, p. 426-427, 2014.

GURDEK, R.; ACUÑA-PLAVAN, A. Intra-annual lengthweight relationships for juveniles of Micropogoniasfurnieri (Desmarest, 1823) in a sub-estuarine system from Uruguay. Panam. J. Aquat. Sci., v. 11, n. 2, p. 165-169, 2016.

GURDEK, R.; DE LA ROSA, A.; CORRALES, D.; CANAVESE, R.; GUTIERREZ, J. M.; STEBNIKI, S.; MUÑOZ, N.; SEVERI, V.; ACUÑA PLAVAN, A. Estuarine use and composition of fish species in the Solís Grande sub-estuary, Uruguay. Panam. J. Aquat. Sci., v. 11, n. 1, p. 82-86, 2016.

GURDEK, R.; MUÑOZ, N.; PUPPI, V.; BIANCHINOTTI, V.; ACUÑA PLAVAN, A. Variación nictimeral de la ictiofauna de la región estuarial del Arroyo Solís Grande, Uruguay. Bol. Soc. Zool. (Uruguay)., v. 20, p. 11-21, 2011.

GUTIÉRREZ, J. M.; VILLAR, S.; ACUÑA PLAVAN, A. Micronucleus test in fishes as indicators of environmental quality in subestuaries of the Río de la Plata (Uruguay). Mar. Poll. Bull., v. 91, n. 2, p. 518-523, 2015.

GUTIÉRREZ-ESTRADA, J. C.; VASCONCELOS, R.; COSTA, M. J. Estimating fish community diversity from environmental features in the Tagus estuary (Portugal): Multiple linear regression and artificial neural network approaches. J. Appl. Ichthyol., v. 24, n. 2, p. 150-162, 2008.

HARRISON, T. D.; WHITFIELD, A. K. Temperature and salinity as primary determinants influencing the biogeography of fishes in South African estuaries. Estuar. Coast. Shelf Sci., v. 66, n. 1-2, p. 335-345, 2006.

JAMES, N. C.; COWLEY, P. D.; WHITFIELD, A. K.; LAMBERTH, $\mathrm{S}$. J. Fish communities in temporarily open/closed estuaries from the warm- and cool-temperate regions of South Africa: a review. Rev. Fish Biol. Fish., v. 17, n. 4, p. 565-580, 2007.

JAUREGUIZAR, A. J.; BAVA, J.; CAROZZA, R. C.; LASTA, C. A. Distribution of whitemouth croaker Micropogonias furnieri in relation to environmental factors at the Río de la Plata estuary, South America. Mar. Ecol. Prog. Ser., v. 255, p. 271-282, 2003 a.

JAUREGUIZAR, A. J.; MENNI, R.; BREMEC, C.; MIANZAN, H.; LASTA, C. Fish assemblage and environmental patterns in the Río de la Plata estuary. Estuar. Coast. Shelf Sci., v. 56, n. 5-6, p. 921-933, 2003b.

JAUREGUIZAR, A. J.; MENNI, R.; GUERRERO, R.; LASTA C. Environmental factors structuring fish communities of the Río de la Plata estuary. Fish. Res., v. 66, n. 2-3, p. 195-211, 2004.

JAUREGUIZAR, A. J.; MENNI, R.; LASTA, C.; GUERRERO, R. Fish assemblages of the northern Argentine coastal system: spatial patterns and their temporal variations. Fish. Oceanogr., v. 15, n. 4, p. 326-344, 2006.

JAUREGUIZAR, A. J.; SOLARI, A.; CORTÉS, F.; MILESSI, A. C.; MILITELLI, M. I.; CAMIOLO, M. D.; LUZ CLARA, M.; GARCÍA, M. Fish diversity in the Río de la Plata and adjacent waters: an overview of environmental influences on its spatial and temporal structure. J. Fish Biol., v. 89, n. 1, p. 569-600, 2016. 
LAGOS, N. Distribución de los juveniles de corvina rubia (Micropogonias furnieri, Scienidae) en el estuario del Río de la Plata. Informe Proyecto FREPLATA. Argentina: (PNUD/GEF/RLA/99/G31)-INIDEP, 2003, 22 p.

LLOMPART, F. M.; COLAUTTI, D. C.; MAIZTEGUI, T.; CRUZ-JIMÉNEZ, A. M.; BAIGÚN, C. R. Biological traits and growth patterns of pejerrey Odontesthes argentinensis. J. Fish Biol., v. 82, n. 2, p. 458-74, 2013.

LORENZO, M. I.; DÍAZ DE ASTARLOA, J. M.; NORBIS, W.; COUSSEAU, M. B. Long term fish assemblages as units of management in a temperate estuary (Río de la Plata - SW Atlantic Ocean). Braz. J. Oceanogr., v. 59, n. 1, p. 43-59, 2011.

MARTÍNEZ, G.; RETTA, S. Caracterización de las áreas de cría de corvina (Micropogonias furnieri) en la zona costera uruguaya. In: VIZZIANO, D.; PUIG, P.; MESONES, C.; NAGY, G. (Eds.). El Río de la Plata. Investigación para la Gestión del Ambiente, los Recursos Pesqueros y la Pesquería en el Frente Salino. Montevideo: Programa EcoPlata, 2002. p. 141-148.

MCLUSKY, D. S.; ELLIOTT, M. The Estuarine Ecosystem: ecology, threats and management. $3^{\text {rd }}$ ed. Oxford: University Press, 2004. 216 p.

Militelli, M. I.; MACCHI, J. G.; RODRÍGUEZ, K. A. Comparative reproductive biology of Sciaenidae family species in the Río de la Plata and Buenos Aires Coastal Zone, Argentina. J. Mar. Biol. Assoc. UK., v. 93, n. 2, p. 413-423, 2013.

MÖLlER JR, O. O.; PIOLA, A. R.; FREITAS A. C.; CAMPOS, E. J. D. The effects of river discharge and seasonal winds on the shelf off Southeastern South America. Cont. Shelf Res., v. 28, n. 13, p. 1607-1624, 2008.

MORESCO, A.; BEMVENUTI, M. D. A. Biologia reprodutiva do peixe-rei Odontesthes argentinensis (Valenciennes) (Atherinopsidae) da região marinha costeira do sul do Brasil. Rev. Bras. Zool., v. 23, n. 4, p. 1168-1174, 2006.

NAGY, G. J.; SEVEROV, D. N.; PSHENNIKOV, V. A.; DE LOS SANTOS, M.; LAGOMARSINO, J. J.; SANS. K.; MOROZOV, E. G. Río de la Plata estuarine system: Relationship between river flow and frontal variability. Adv. Space Res., v. 41, 11, p. 1876-1881, 2008.

NICOLAS, D.; LOBRY, J.; LE PAPE, O.; BOËT, P. Functional diversity in European estuaries: Relating the composition of fish assemblages to the abiotic environment. Estuar. Coast. Shelf Sci., v. 88, n. 3, p. 329-338, 2010.

NORBIS, W.; PAESCH, L.; GALLI, O. Los recursos pesqueros de la costa de Uruguay: ambiente, biología y gestión. In: MENAFRA, R.; RODRÍGUEZ-GALLEGO, L.; SCARABINO, F.; CONDE, D. (Eds.). Bases para la conservación y el manejo de la costa uruguaya. Montevideo: Vida Silvestre Uruguay, 2006, p. 197-209.

PASSADORE, C.; GIMENEZ, L.; ACUÑA PLAVAN, A. Composition and intra-annual variation of the macroinfauna in the estuarine zone of the Pando Stream (Uruguay). Braz. J. Biol., v. 67, n. 2, p. 197-202, 2007.

PIOLA, A. R.; MATANO, R. P.; PALMA, E. D.; MÖLLER JR, O. O.; CAMPOS, E. J. D. The influence of the Plata River discharge on the western South Atlantic shelf. Geophys. Res. Lett., v. 32, n. 1, p. 1603-1606, 2005.
PIOLA, A. R.; ROMERO, S. I.; ZAJACZKOVSKI, U. Spacetime variability of the Plata plume inferred from ocean colour. Cont. Shelf Res., v. 28, n. 13, p. 1556-1567, 2008.

POTTER, I. C.; HYNDES, G. A. Characteristics of the ichthyofaunas of southwestern Australia estuaries, including comparison whit Holarctic estuaries and estuaries elsewhere in temperate Australia: A review. Aust. J. Ecol., v. 24, n. 4, p. 395-421, 1999.

RAMOS, L. A.; VIEIRA, J. P. Composição específica e abundância de peixes de zonas rasas dos cinco estuários do rio Grande do Sul, Brasil. Bol. Inst. Pesca, v. 27, n. 1, p. 109121, 2001.

RETTA, S.; MARTÍNEZ, G.; ERREA, A. Áreas de cría de especies de peces en la costa uruguaya. In: MENAFRA, R.; RODRÍGUEZGALLEGO, L.; SCARABINO, F.; CONDE, D. (Eds.). Bases para la conservación y manejo de la costa uruguaya. Montevideo: Vida Silvestre Uruguay, 2006, p. 211-217.

SELLESLAGH, J.; AMARA, R. Environmental factors structuring fish composition and assemblages in a small macrotidal estuary (eastern English Channel). Estuar. Coast. Shelf Sci., v. 79, n. 3, p. 507-517, 2008.

SHANNON, C. E.; WEAVER, W. The Mathematical Theory of Communication. Urbana: University of Illinois Press, 1963.

SHAPIRO, S. S.; WILK, M. B. An analysis of variance test for normality (Complete samples). Biometrika, v. 52, n. 4-3, p. 591-611, 1965.

SIMPSON, E. H. Measurement of diversity. Nature, v. 163, p. $688,1949$.

SOKAL, R. R.; ROHLF, J. F. Biometry: the Principles and Practice of Statistics in Biological Research. $3^{\text {rd }}$ ed. New York: Freeman WH and Company, 1995. 887 p.

SOLARI, A. Variación espacio-temporal de la ictiofauna en hábitats someros del área sur de la Bahía Samborombón. 2013. 217 f. Tesis (Doctorado). Facultad de Ciencias Naturales y Museo. Argentina: Universidad Nacional de La Plata, 2013.

SOLARI, A.; GARCÍA, M. L.; JAUREGUIZAR, A. J. Fish fauna from the Ajó river in Campos del Tuyú National Park, province of Buenos Aires, Argentina. Check List (Campinas). v. 5, n. 4, p. 807-811, 2009.

SOLARI, A.; JAUREGUIZAR, A. J.; MILESSI, A. C., GARCÍA, M. L. Fish assemblages in a small temperate estuary on the Argentinian coast: spatial variation, environmental influence and relevance as nursery area. Braz. J. Oceanogr., v. 63, n. 3, p. 181-194, 2015.

TEIXEIRA DE MELLO, F.; GONZÁLEZ-BERGONZONI, I.; LOUREIRO, M. Peces de agua dulce del Uruguay. Montevideo: Proyecto de Producción Responsable-Ministerio de Ganadería Agricultura y Pesca, 2011. 188 p.

THIEL, R.; SEPÚLVEDA, A.; KAFEMANN, R.; NELLEN, W. Environmental factors as forces structuring the fish community of the Elbe Estuary. J. Fish Biol., v. 46, n. 1, p. 47-69, 1995.

VALESINI, F. J.; POTTER, I. C.; CLARKE, K. R. To what extent are the fish compositions at nearshore sites along a heterogeneous coast related to habitat type? Estuar. Coast. Shelf Sci., v. 60, n. 4, p. 737-754, 2004.

VASCONCELOS, R. P.; REIS-SANTOS, P.; CABRAL, H. N.; COSTA, J. L.; COSTA, M. J. River-Coast Connectivity, Estuarine Nursery Function and Coastal Fisheries. In: WOLANSKI, E.; MCLUSKY, D. S. (Eds.). Treatise on Estuarine and Coastal Science. Volume 10: Ecohydrology and Restoration. London: Academic Press, 2011. p. 81-107. 
VEIGA, P.; VIEIRA, L.; BEXIGA, C.; SÁ, R.; EEZINI, K. Structure and temporal variations of fish assemblages of the Castro Marim salt marsh, southern Portugal. Estuar. Coast. Shelf Sci., v. 70, n. 1-2, p. 27-38. 2006.

VIEIRA, J. P.; MUSICK, J. A. Fish fauna composition in warm temperate and tropical estuaries of western Atlantic. Atlântica (Rio Grande), v. 16, p. 31-53, 1994.
WHITFIELD, A. K. Ichthyofaunal assemblages in estuaries: A South African study. Rev. Fish Biol. Fisher, v. 9, n. 2, p. 151$186,1999$.

WHITFIELD, A. K.; ELLIOTT, M. Fishes as indicators of environmental and ecological changes within estuaries: a review of progress and some suggestions for the future. $J$. Fish Biol., v. 61, n. sA, p. 229-250, 2002. 